\title{
Association of BRCA1 (G22231T, T25025A, C28300A) polymorphisms with subclinical mastitis and milk yields in Holstein Cattle
}

\author{
Fadime DALDABAN ${ }^{1, a,{ }^{*}}$, Korhan ARSLAN ${ }^{1, b}$, Aytaç AKÇAY ${ }^{2, c}$, Mahmodul Hasan SOHEL ${ }^{1, d}$, \\ Bilal AKYÜZ ${ }^{1, e}$
}

\author{
${ }^{1}$ Department of Genetics, Faculty of Veterinary Medicine, Erciyes University, Kayseri, Turkey. \\ 2Department of Biostatistics, Faculty of Veterinary Medicine, Ankara University, Ankara, Turkey \\ aORCID: 0000-0001-5795-8859, bORCID: 0000-0002-2440-884X, 'ORCID: 0000-0001-6263-5181, dORCID: 0000-0003-2224-
} 085X, eORCID: 0000-0001-7548-9830

\begin{abstract}
In this study, it was aimed to investigate the relationship between three SNP on the BRCA1 gene and subclinical mastitis, as well as milk yields during four lactation periods in Holstein breed cattle. The animal material of the study consisted of 151 Holstein cows reared under the same care and feeding conditions. Complete DNA was isolated from blood samples by using phenol: chloroform: isoamyl alcohol method. Genotyping of G22231T, T25025A and C28300A SNPs on the BRCA1 was done by the PCR-RFLP method. Subclinical mastitis of animals was determined in milk samples by California Mastitis Test (CMT). In the study, CMT data, four lactation periods' milk yields, and proportional distributions of SNP genotypes were calculated. Statistical significance of the data was determined by the Pearson chi-square test. The relationship between C28300A SNP, which was monomorphic, and subclinical mastitis has not been analyzed. In the samples examined, the difference between the proportional distribution of SNP genotypes of G22231T and T25025A in subclinical mastitis and healthy groups was not found statistically significant $(P>0.05)$. As a result of the Chi-square $(\chi 2)$ analysis conducted, it was observed that the Holstein cattle were in the Hardy-Weinberg equilibrium in terms of G22231T and T25025A SNPs. Considering the physiological processes in which the BRCA1 gene is involved, it was thought that these genes and SNPs should be evaluated with more samples in studies on resistance to mastitis.
\end{abstract}

Keywords: BRCA1 gene, Holstein, Mastitis, PCR-RFLP.

\section{BRCA1 (G22231T, T25025A, C28300A) polimorfizmlerinin Holştayn Sığırlarında subklinik mastitis ve süt verimi ile ilişkisi}

Özet: Bu çalışmanın amacı Holstein ırkı sığırlarda BRCA1 geninde meydana gelen üç farklı tek nokta mutasyonun, subklinik mastitis ve süt verimi arasındaki ilişkinin araştırılmasıdır. Bu amaçla hayvan materyali olarak aynı bakım ve beslenme koşullarına sahip 151 dişi Holstein ırkı sığır seçildi ve bu sığırların dört laktasyon dönemi boyunca verim kayıtları kullanıldı. Total DNA, kan örneklerinden fenol:kloroform:izoamil alkol yöntemiyle izole edildi. Elde edilen DNA örneklerinden BRCA1 genindeki G22231T, T25025A ve C28300A tek nokta mutasyonları için PCR-RFLP yöntemi ile genotipleme yapıldı. Hayvanlarda subklinik mastitisinin bulunup bulunmadığı, süt örneklerine yapılan California Mastitis Testi (CMT) ile belirlendi. Çalışmada CMT verileri, dört laktasyon dönemi süt verim bilgileri ve tek nokta mutasyonları sonucu ortaya çıkan genotiplerinin orantılı olarak dağılımları hesaplanmıştır. Verilerin istatistiksel anlamlıı̆ı Pearson ki-kare testi ile yapılmıştır. Incelenen örneklerde monomorfik olan C28300A tek nokta mutasyonunun subklinik mastitis ile bir ilişkisi analiz edilmemiştir. G22231T, T25025A tek nokta mutasyonlarından sonra oluşan genotiplerin ise orantılı dağılımı arasındaki fark istatistiksel olarak anlamlı bulunmamıştır ( $P>0.05)$. Yapılan Ki-kare $(\chi 2)$ analizi sonucunda Holstein ırkı sığırların G22231T ve T25025A tek nokta mutasyonları açısından Hardy-Weinberg dengesinde olduğu görülmüştür. BRCA1 geninin görev aldığı fizyolojik süreçler göz önüne alındığında mastitise direnç ile ilgili çalışmalarda bu gen ve SNP'lerin daha çok örnekle değerlendirilmesi gerektiği düşünülmüştür.

Anahtar Kelimeler: BRCA1 Geni, Holstein, Mastitis, PCR-RFLP.

\section{Introduction}

Several reasons including personal taste and level of income greatly influence food consumption habits. Milk and dairy products play an important role in the adequate and balanced nutrition of people. Among the milk and dairy products consumed throughout the world, approximately $96 \%$ is obtained from large ruminates such as cattle and buffalo (Yalçın and Argun, 2017). Among the existing cattle breeds, the Holstein breed has been the most popular dairy cattle breed in the world regardless of geography and climatic belt because of high milk yield capacity, the suitability of the udder structure and the teat structure to modern milking systems (Yaylak et al., 2015). In addition to milk yielding capacity, Holstein males have been shown to be good quality meat producers. In the 
last few decades, the primary objective of Holstein breeding was to improve production traits such as milk yield, whereas others such as reproductive and disease-related traits were overlooked. Therefore, despite the high milk yield of Holstein cattle, their reproductive performance is poor and they are susceptible to many diseases including mastitis (Blöttner et al., 2011). Selection studies to increase milk yield in dairy cattle reduced resistance to mastitis due to the negative correlation between them. For example, due to the genetic correlation between milk fat or protein yield and mastitis ranging from 0.25 to 0.50 , long-term selections to improve these properties have led to a decrease in resistance to mastitis (Weigel and Shook, 2018). Therefore, breeding strategies for improving resistance to diseases stands out as an important feature-(Egger-Danner et al., 2014). In the case of dairy cattle, several diseases including tuberculosis, brucellosis, and mastitis cause significant economic losses. It is important to note that vaccination and restrictions on the movement of animals and animal products could decrease the prevalence of diseases like tuberculosis and brucellosis, especially in developed countries (Claridge et al., 2012). However, mastitis, which is defined as the inflammatory response of the mammary gland to microbial, traumatic, or toxic agents, is common all over the world. Mastitis is a disease that causes serious economic losses in dairy cows by significantly reducing the quality and quantity of milk (Halasa et al., 2007; Kumar et al., 2010; Weigel and Shook, 2018). In addition, mastitis significantly increases the risk of the culling of animals by 2-4 folds due to problems related to conception as well as the continuation of the pregnancy (Weigel and Shook, 2018). At the same time, the use of antibiotics to treat mastitis accounts for half of all antibiotics used in a dairy farming, causing significant economic losses and environmental pollution (Francoz et al., 2017; Saini et al., 2012; Weigel and Shook, 2018).

Although a combination of early diagnosis and effective antimicrobial drugs have been at the forefront in the prevention of economic losses (caused by mastitis due to atrophy of the under, loss of breeding value of the animal, and the long and expensive treatment process), there has been an increasing interest in the development of genetically mastitis-resistant flocks in recent years. Studies have shown that there is a strong relationship between some genes and resistance to mastitis. Therefore, there is increasing interest in developing mastitis-resistant herds. ( Asaf et al., 2014a; Asaf et al., 2014b; Jacob et al., 2018; Rupp et al., 2007; Tolone et al., 2016; Youngerman et al., 2004). Breast cancer 1 (BRCA1) gene is one of those genes that has been reported to be associated with hereditary breast cancer risk in humans (Friedman et al., 1994) as well as mastitis in cattle (Yuan et al., 2012b).

The BRCA1 gene, a member of the RING-type chain fingers (RNF) family, belongs to a class of genes known as tumor suppressor genes that encode proteins that help to prevent rapid growth and division of cells (Wang et al., 2000). Other tumor suppressors, together with DNA damage sensors and signal transducers, form a large, multipart protein complex known as the BRCA1-related genome surveillance complex (BASC) (Wang et al., 2000).

The $B R C A 1$ gene, involved in the regulation of the cell cycle, is directly involved in the repair of DNA damage and other pathways involved in maintaining the stability of the genome (Wang et al., 2000). There are four transcript variants of the BRCA1 gene (Krum et al., 2003), 6059 bp, 5550 bp, $5526 \mathrm{bp}$, and $2115 \mathrm{bp}$ defined in the Ensemble database, and consist of 22 exons and 21 introns (Ensembl, 2020). BRCA1 gene was found to be associated with the somatic cell score (SCS) (Bennewitz et al., 2004; Daetwyler et al., 2008). Studies have reported a positive correlation between SCS and mastitis in cattle, ranging from 0.30 to 0.98 , with an average of 0.70 (Chu et al., 2012; Heringstad et al., 2006; Yuan et al., 2012). Therefore, a selection study to improve SCS may also contribute to the development of a mastitisresistant dairy herd. In previous studies, it has been reported that there is a positive correlation between BRCA1 gene, and SCC which is positively correlated with mastitis. However, the relationship between different SNPS on the BRCA1 gene and subclinical mastitis in Holstein cattle is not well understood. Therefore, the aim of this study was to investigate the relationship between lactation milk yields and subclinical mastitis with three different SNPS on the BRCA1 gene in Holstein cows.

\section{Material and Method}

A total of 151 female Holstein cattle reared around Kayseri were used in this study. Ethics Committee Approval to use animal materials was obtained from Erciyes University Animal Experiments Local Ethics Committee on the date 11.12.2013, with an identification number of $13 / 157$.

Subclinical Mastitis Test: California Mastitis Test (CMT) was employed to determine the subclinical mastitis conditions using milk samples. Briefly according to Fthenakis, 1995: in the $2 \mathrm{ml}$ milk sample taken separately from the udder lobe of the animal was placed separately in the CMT test disc. 
The CMT solution was added into the milk in the CMT disc and the CMT disc was shaken orbitally. If coagulation was observed, the presence of mastitis in the udduer was concluded. In addition, the milk yield records for the first four lactations were examined.

DNA Isolation and PCR-RFLP: All lab procedures were performed according to the guidelines of the Local Ethics Committee for Animal Experiments at Erciyes University (14.06.2017 and 17/056). $9 \mathrm{ml}$ blood samples were collected from the vena jugularis of experimented animals into tubes containing EDTA. DNA was isolated from whole blood using the phenol: chloroform: isoamylalcohol method (Sambrook et al., 1989). The purity and concentration of isolated DNA were measured using a Nanodrop Spectrophotometer (BioTek, Synergy H1 Hybrid Multi-Mode Microplate Reader). A PCR-RFLP was performed (Qiagen, Sensoquest) to investigate three SNPs, namely BRCA1-1 (G22231T),
BRCA1-2 (T25025A), and BRCA1-3 (C28300A), on the bovine $B R C A 1$ gene. The PCR reaction contained $2.5 \mathrm{mM} \mathrm{MgCl} 2,50 \mu \mathrm{M}$ dNTP mix, $0.2 \mu \mathrm{M}$ forward and reverse primer, $1.25 \mathrm{U}$ Taq DNA polymerase and $50 \mathrm{ng} / \mu \mathrm{LNA}$ and nuclease free water to obtain a final volume of $20 \mu \mathrm{l}$ for each sample. The thermal cycles of PCR reaction were set up as follows: a pre-denaturation temperature of 5 minutes at $94{ }^{\circ} \mathrm{C}, 30$ seconds at $94{ }^{\circ} \mathrm{C}, 30$ seconds at $72{ }^{\circ} \mathrm{C}$, at the appropriate annealing temperature specified in Table 1 for each SNP region. After the number of cycles specified in Table 1 was completed, it was completed by standing at $72^{\circ} \mathrm{C}$ for $7 \mathrm{~min}$.

The amplicons obtained from PCR were visualized in a $2 \%$ agarose gel and the amplicons for each SNP were treated with the appropriate restriction enzymes (Table 1 ) at the appropriate temperatures. Genotypes of each individual were examined by $2 \%$ agarose gel electrophoresis.

Table 1. Primer and amplicon sizes of BRCA1 gene SNP regions

\begin{tabular}{|c|c|c|c|c|c|c|c|c|c|}
\hline SNP & & Primary Sequence (3'-5') & AT & C & Amplicon & RE & Genotype & Bands(bp) & $\operatorname{RET}\left({ }^{\circ} \mathrm{C}\right)$ \\
\hline G22231T & $\begin{array}{l}\mathrm{F} \\
\mathrm{R}\end{array}$ & $\begin{array}{l}\text { CTTCAGAACCTGTACTTGTAACC } \\
\text { CAAGGAATATTTACTGAGCACC }\end{array}$ & 55 & 32 & $321 b p$ & Hhal & $\begin{array}{l}A A \\
A B \\
B B\end{array}$ & $\begin{array}{l}272,49 \\
321,272,49 \\
321\end{array}$ & 37 \\
\hline $\mathrm{T} 25025 \mathrm{~A}$ & $\begin{array}{l}\mathrm{F} \\
\mathrm{R}\end{array}$ & $\begin{array}{l}\text { TGCAGTGGAAATTCCAAATAAACT } \\
\text { GAATTAGATCTTCAGCTATGTGGC }\end{array}$ & 60 & 32 & $209 \mathrm{bp}$ & Mael & $\begin{array}{l}C C \\
C D \\
D D\end{array}$ & $\begin{array}{l}185,24 \\
209,185,24 \\
209\end{array}$ & 37 \\
\hline C28300A & $\begin{array}{l}\mathrm{F} \\
\mathrm{R}\end{array}$ & $\begin{array}{l}\text { AGAGGAAATCATCTGGGTGTCC } \\
\text { CCTTGTGCTTTTTACCTGAGTGC }\end{array}$ & 58.3 & 38 & $217 b p$ & BspTI & $\begin{array}{l}E E \\
E F \\
F F\end{array}$ & $\begin{array}{l}190,27 \\
217,190,27 \\
217\end{array}$ & 37 \\
\hline
\end{tabular}

F: Forward, R: Reverse, bp: Baz pair AT: Anneling Temperature, C: PCR Cyle RE: Restriction endonuclease, RET: Restriction endonuclease enzyme cutting heat

Statistical analysis: Based on the subclinical mastitis status of the animal, the mean and standard deviation values of lactation milk yields were calculated with the NCSS 9.0 package program. Proportional distributions of the genotypes determined according to three SNPs and regions on the BRCA1 gene were calculated in accordance with the subclinical mastitis status and statistical significance controlled by the Pearson Chi-square test.

\section{Results}

Three different SNP regions in the BRCA1 gene were genotyped by PCR-RFLP method.

The results of PCR-RFLP analysis for the BRCA1 gene showed a $321 \mathrm{bp} \mathrm{PCR}$ band for G22231T, 209 bp for T25025A, and 217 bp for C28300A (Figure 1).
In G2223T region, two bands of 272 and 49 bp in individuals with $A A$ genotypes, three bands of 321,272 , and 49 bp individuals with $A B$ genotype, and one band of $321 \mathrm{bp}$ individuals with $B B$ genotype has been observed. In T2505AT region, two bands of 185 and $24 \mathrm{bp}$ in individuals with CC genotypes, three bands of 209, 185, and $24 \mathrm{bp}$ individuals with CD genotype, and one band of 209 bp individuals with DD genotype has been observed .For C28300A regions, the EF and FF genotypes were not found in animals examined. Enzyme cutting images of three SNPs in BRCA1 gene are show in Figure 2. Bands used in genotype analysis of SNP regions are presented in Table 1.

Genotype frequencies of $A A, A B$ and $B B$ for the G22231T SNP region were $0.12,0.54$, and 0.31 , respectively while allele frequencies of $A$ and $B$ allels were 0.40 and 0.60 , respectively $(P>0.05)$. 
Frequencies of $C C, C D$ and $D D$ genotypes for the T25025A SNP region were $0.68,0.28$, and 0.02 , respectively, while frequencies of $C$ and $D$ alleles were 0.83 and 0.17 , respectively $(P>0.05)$ (Table 2 ).

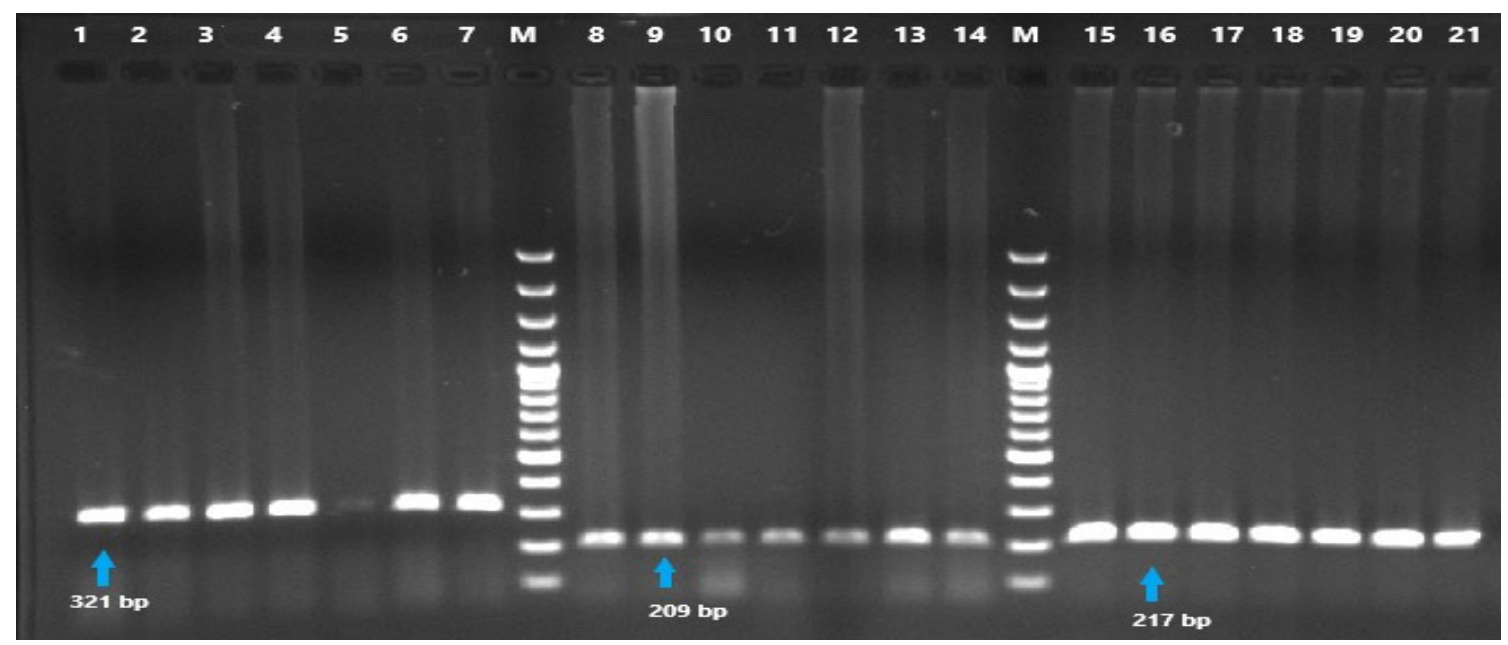

Figure 1. BRCA1 gene SNP regions PCR result (1-7: 321 bp (G22231T SNP), 8-14:209 bp (T25025A SNP) and 15-21: 217 bp (C28300A SNP), M: 100 bp Ladder; bp: base pair)

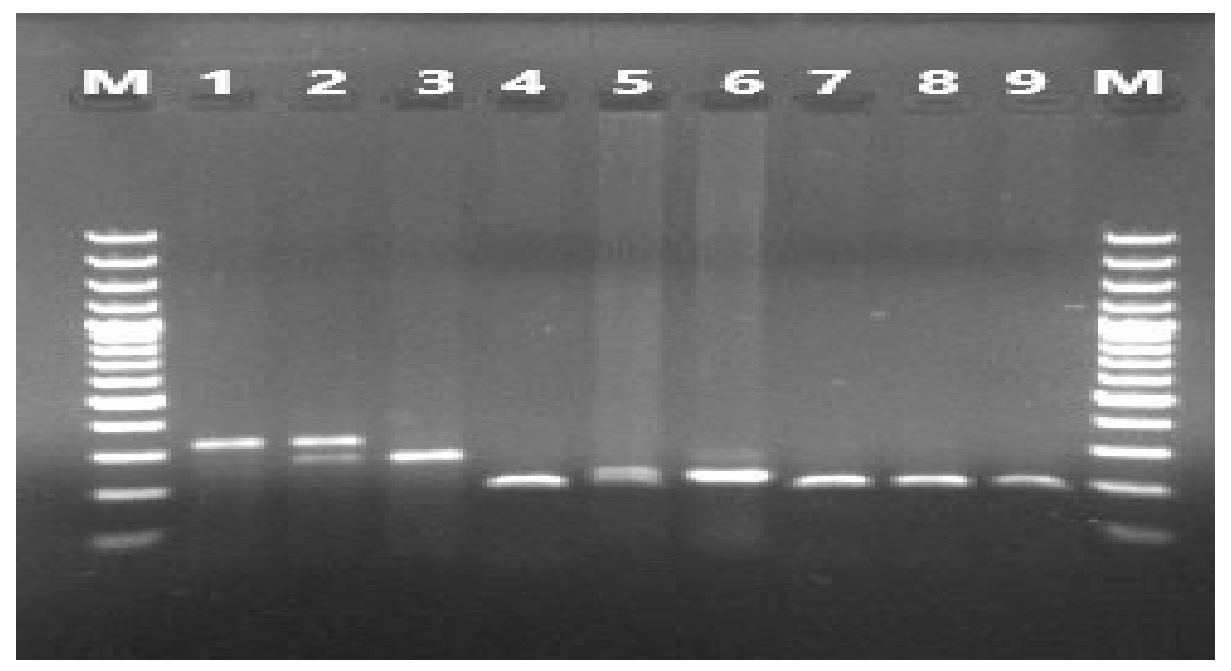

Figure 2: Enzyme PCR-RFLP images of three SNPs in the BRCA1 gene (M: 100 bp ladder, 1: BB genotype, 2: $A B$ genotype, 3: AA genotype, 4: $C C$ genotype, 5:DD genotype, 6: $C D$ genotype, 7-9: EE genotype)

Table 2. BRCA1 gene allele and genotype frequencies in Holstein cattle

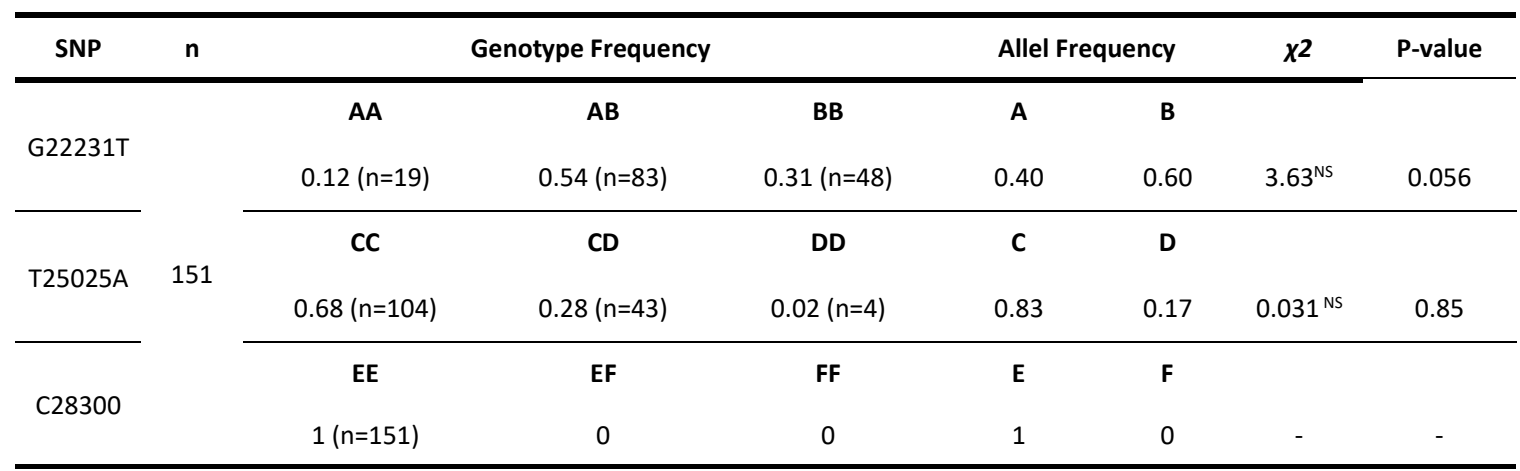

$\mathrm{n}$ : Number of animals, $\chi 2$ : Chi-square ${ }^{\text {NS}}$ : Not significant

Since the examined samples were monomorphic in terms of C28300A polymorphism, the relationship between these SNPs and subclinical mastitis could not be analyzed. No significant differences $(P>0.05)$ were found between the subclinical mastitis and the proportional 
distribution of genotypes in G22231T and T25025A SNPs. However, $57.8 \%$ (48/83) of subclinical mastitis positive $(\mathrm{M}+)$ animals carried $A B$ genotype in terms of G22231T polymorphism, while for T25025A polymorphism, genotype CC showed the highest frequency with $54.8 \%$ (57/104) (Table 4). In addition, $35.37 \%(29 / 82)$ of the cattle with subclinical mastitis $(M+)$ were found to have both the G22231T gene $A B$ and the T25025A gene CC genotype.

Table 3. Lactation milk yields according to subclinical mastitis status

\begin{tabular}{clcccc}
\hline $\begin{array}{c}\text { Subclinical } \\
\text { Mastitis }\end{array}$ & Lactation Milk Yields & N & Minimum & Maximum & $\begin{array}{c}\text { Mean } \pm \\
\text { Std.Deviation }\end{array}$ \\
\hline \multirow{2}{*}{ M(-) } & Daily Milk Yield & 69 & 13.6 & 31.2 & $24.8 \pm 4.2$ \\
& Number of Days & 69 & 278 & 418 & $346.0 \pm 31.1$ \\
& Total Efficiency & 69 & 4404.4 & 11180.8 & $8506.7 \pm 1447.1$ \\
\hline \multirow{2}{*}{$\mathbf{M}(+)$} & Daily Milk Yield & 82 & 12.8 & 31.1 & $24.3 \pm 3.5$ \\
& Number of Days & 82 & 285 & 440 & $356.9 \pm 35.5$ \\
& Total Efficiency & 82 & 4672.4 & 11290.6 & $8621.4 \pm 1306.1$ \\
\hline
\end{tabular}

$\mathrm{n}$ : Number of animal samples

Table 4. Proportional distribution and statistical significance controls of genotypes according to subclinical mastitis status

\begin{tabular}{|c|c|c|c|c|c|}
\hline \multirow[b]{2}{*}{ SNP } & \multirow[b]{2}{*}{ Genotype } & \multicolumn{3}{|c|}{ Genotype Frequency } & \multirow{2}{*}{$\begin{array}{l}\text { Pearson ki- } \\
\text { square test (P } \\
\text { value) }\end{array}$} \\
\hline & & $M(-)$ & $M(+)$ & Total (n) & \\
\hline \multirow{3}{*}{ G22231T } & AA & 11 (57.9\%) & $8(42.1 \%)$ & 19 & \multirow{3}{*}{0.452} \\
\hline & $A B$ & 35 (42.2\%) & $48(57.8 \%)$ & 83 & \\
\hline & BB & $23(46.9 \%)$ & $26(53.1 \%)$ & 49 & \\
\hline \multirow{3}{*}{ T25025A } & $\mathrm{CC}$ & $47(45.2 \%)$ & $57(54.8 \%)$ & 104 & \multirow{3}{*}{0.437} \\
\hline & $C D$ & $21(50.0 \%)$ & $21(50.0 \%)$ & 42 & \\
\hline & DD & $1(20.0 \%)$ & $4(80.0 \%)$ & 5 & \\
\hline \multirow{3}{*}{ C28300A } & $\mathrm{EE}$ & $69(45.7 \%)$ & $82(54.3 \%)$ & 151 & \multirow{3}{*}{-} \\
\hline & $\mathrm{EF}$ & - & - & & \\
\hline & $\mathrm{FF}$ & - & - & & \\
\hline
\end{tabular}

M: Mastitis

\section{Discussion and Conclusion}

There are two types of mastitis known as clinical and subclinical mastitis, which are the most common in the dairy industry and cause serious economic loss (Gabrielli et al., 2015). In the case of clinical mastitis, there are visible changes in milk and udder structure. However, changes in milk and udder in subclinical mastitis cannot be determined visually (Zorba and Tepeli, 2017). As a result of decreased milk yield in affected animals and the decreased quality of milk products due to the mixing of the milk obtained from sick animals with healthy milk, significant losses arise in both the enterprise and the national economy (Aytekin and
Boztepe, 2014; Guerrero et al., 2015). In fact, it has been reported that about $70 \%$ of the economic losses due to mastitis are caused by subclinical mastitis (Janzen, 1970). On the other hand, 45-60 subclinical cases have been reported for each clinical mastitis case in a dairy cattle herd (Çoban, 2007). Therefore, for the prevention of economic losses caused by subclinical mastitis, early diagnosis as well as the development of disease-resistant individuals are important and highly desirable by the producers.

The diagnosis of clinical mastitis in the field is very important and can be done using udder examination, physical properties of milk, somatic cell count, and ultrasonography. However, the 
diagnosis of subclinical mastitis is comparatively difficult because the majority of the tests are dependant on indirect tests such as tissue damagerelated enzyme (i.e. HDL and NAGase) examination, electronic conductivity, and California Mastitis Test (CMT). The majority of these tests are less sensitive and could give false-positive test results. Therefore, molecular techniques such as PCR-RFLP can be used to select animals that are genetically resistant or susceptible to subclinical mastitis.

In the current study, we investigated the relationship between subclinical mastitis and three SNPs in the BRCA1 gene, which has been reported as a potential candidate gene to detect mastitis in Chinese commercial cattle (Yuan et al., 2012) and subclinical mastitis in buffaloes (Biendima and Ramos, 2017). Chi-square ( $\chi 2$ ) analysis showed that Holstein breed cattle were in Hardy-Weinberg equilibrium in terms of G22231T and T25025A coded SNPs. It is interesting to note that the G22231T coded SNP was found in all three genotypes, where the $A B$ genotype was the most frequent (0.54). In agreement with our results, Yuan et al. (2012) reported that there are three genotypes in Holstein grown in China where the $A B$ genotype (0.57) is the most common. In addition, the authors also investigated Scene and Simental breeds and reported that the $A B$ genotype was the most common genotype in both breeds (Yuan et al., 2012). Comparatively a higher frequency of $A B$ genotype (0.78) was reported in the crossbreed of Holstein $\times$ Sahiwal grown in India. Surprisingly, in contrast to our results, the authors reported an absence of $B B$ genotype in the same population (Deb et al., 2014). The higher frequency of $A B$ genotype and the absence of $\mathrm{BB}$ genotype in the crossbred population could be due to the presence of the Sahiwal breed (Bos indicus). However, further studies are required to confirm this hypothesis.

In the case of T25025A SNP, our results showed that in the cattle of Holstein breed, the CC genotype has the highest frequency $(0.68)$, while the DD genotype has the lowest frequency (0.02). These results are consistent with the findings of Yuan et al. (2012b). In contrast to others and our results, Deb et al. (2014) did not observe any individuals with CC genotypes in Frieswal crossbred. This deviation could be due to the same reason as stated before- the presence of Bos indicus gene in that population. On the other hand, in the case of C28300A SNP, surprisingly, we found that all the animals carried EE genotype. In contrast to our results, Yuan et al. (2012b) showed the presence of all three genotypes (EE, EF, and FF) in the Holstein breeds reared in China, although the EE genotype showed the highest frequency.
In a study investigating the relationship between the three SNPs and somatic cell score in the milk (SCS) of the Holstein, Simental, and Sahne breeds, EE genotype of C28300A locus was reported to be associated with lower SCS (Yuan et al., 2012b). Similarly, Deb et al. (2014) reported that there is a relationship between AA genotype of G22231T locus as well as CD genotype of T25025A locus and SCS in the Frieswal race, a Holstein $\times$ Sahiwal (Bos indicus) hybrid. Similar results were not obtained in two studies of the same feature. This difference may be due to the fact that while the study conducted by Yuan et al., 2012 examined cattle originating from Bos taurus, in the study conducted by Deb et al., 2014, Bos indicus crossbred cattle were examined. In this study where only Holstein cows were examined, unlike the other two studies, the relationship between these SNPs and subclinical mastitis was investigated and, no correlation was found between G22231T and 2 and subclinical mastitis. Similar to the results of this study, Asaf et al. (2015) reported that they did not find a relationship between G22231T and mastitis incidence in Vrindavani, a hybrid breed grown in India. On the other hand, in contrast to the results of this study in terms of the presence of the $E E$ genotype in the C28300A, regions examined was different from the study by Yuan et al., (2012b). In this study, no relationship was found between G22231T and SNPs subclinical mastitis. However, it was observed that the $A B$ genotype for the G22231T polymorphism and CC genotype for T25025A polymorphism was more common than the other genotypes among the group of subclinical mastitis containing 82 Holstein cows.

At the end of the study, it was concluded that increasing the number of samples may contribute to a more accurate explanation of the relationship between the BRCA1 gene and mastitis. In addition, to investigate the relationship between C28300A coded SNP and subclinical mastitis, it was concluded that studies examining more samples should be planned to observe different genotypes.

\section{References}

Asaf VM, Bhushan B, Panigrahi M, Dewangan P, Kumar A, Kumar P, Gaur GK, 2014a: Association study of genetic variants at single nucleotide polymorphism rs109231409 of mannose-binding lectins 1 gene with mastitis susceptibility in Vrindavani crossbred cattle. Vet World, 7 (10), 807-810.

Asaf VM, Kumar A, Rahim A, Sebastian R, Mohan V, Dewangan P, Panigrahi M, 2014b: An overview on single nucleotide polymorphism studies in mastitis Research. Vet World, 7 (6), 416-421. 
Aytekin I, Boztepe S, 2014: Süt sığırlarında somatik hücre sayısı, önemi ve etki eden faktörler. TURJAF, 2, 112121.

Bennewitz J, Reinsch N, Guiard V, Fritz S, Thomsen H, Looft C, Kuhn C, Schwerin M, Weimann C, Erhardt G, Reinhardt F, Reents R, Boichard D, Kalm E, 2004: Multiple quantitative trait loci mapping with cofactors and application of alternative variants of the false discovery rate in an enlarged granddaughter design. Genetics, 168,1019-1027.

Biendima CC, Ramos SC, Uy MRD, Mingala CN, 2017: Molecular Characterization of BRCA1 as Candidate Gene Marker for Subclinical Mastitis in Dairy Water Buffaloes (Bubalus bubalis). PJS, 146 (3), 293-298.

Blöttner S, Heins BJ, Wensch-Dorendorf M, Hansen LB, Swalve HH, 2011: A Comparison between Purebred Holstein and Brown Swiss $\times$ Holstein Cows for Milk Production, Somatic Cell Score, Milking Speed, and Udder Measurements in The First 3 Lactations. J Dairy Sci, 94, 5212-5216.

Chu MX, Ye SC, Qiao L, Wang JX, Feng T, Huang DW, Cao GL, Di R, Fang L, Chen GH 2012: Polymorphism of exon 2 of BoLA-DRB3 gene and its relationship with somatic cell score in Beijing Holstein cows. Mol Biol Rep, 39 (3), 2909-2914.

Claridge J, Diggle P, McCann CM, Mulcahy G, Flynn R, McNai J, Williams DJ, 2012: Fasciola hepatica is associated with the failure to detect bovine tuberculosis in dairy cattle. Nat Commun, 3, 853.

Çoban Ö, Tüzemen N, 2007: Siyah Alaca ve Esmer ineklerde subklinik mastitis için risk faktörleri. Uludag Üniv J Fac Vet Med, 26 (1-2), 27-31.

Daetwyler HD, Schenkel FS, Sargolzaei M, Robinson JA, 2008: A genome scan to detect quantitative trait loci for economically important traits in Holstein cattle using two methods and a dense single nucleotide polymorphism map. J Dairy Sci, 91, 3225-3236.

Deb R, Singh U, Kumar S, Singh R, Sengar G, Sharma A, 2014: Profiling of bovine breast cancer 1 , early onset (BRCA1) gene among Frieswal (HFx Sahiwal) cows and their association with mastitis. Natl Acad Sci Lett, 37 (6), 579-583.

Egger-Danner C., Cole JB, Pryce JE, Gengler N, Heringstad B, Bradley A, Stock KF, 2015: Invited review: overview of new traits and phenotyping strategies in dairy cattle with a focus on functional traits. Animal, 9 (2), 191-207.

Ensembl2020.https://aug2020.archive.ensembl.org/Bos_t aurus/Gene/Summary?db=core;g=ENSBTAG000000 22520;r=19:43069372-43139018, Access date; 01.08.2020.

Francoz D, Wellemans V, Dupré JP, Roy JP, Labelle F, Lacasse P, Dufour S, 2017: Invited review: A systematic review and qualitative analysis of treatments other than conventional antimicrobials for clinical mastitis in dairy cows. J Dairy Sci, 100 (10), 7751-7770.

Friedman LS, Ostermeyer EA, Szabo Cl, Dowd P, Lynch ED, Rowell SE, King MC, 1994: Confirmation of BRCA1 by analysis of germline mutations linked to breast and ovarian cancer in ten families. Nat Genet, 8 (4), 399.
Fthenakis GC, 1995: California Mastitis Test and Whiteside Test in diagnosis of subclinical mastitis of dairy ewes. Small Rumin Res, 16 (3), 271-276.

Gabrielli SS, Lasagno MC, Alencar TA, Ribeiro L, Dubenczuk FC, Oliva MS, Coelho SM, 2015: AmpClactamase production in Enterobacteria associated with bovine mastitis in Brazil. Afr J Microbiol Res, 9 (8), 503-508.

Guerrero A, Dallas DC, Contreras S, Bhandari A, Cánovas A, Islas-Trejo A, Chee S, 2015: Peptidomic analysis of healthy and subclinically mastitic bovine milk. Int Dairy J, 46, 46-52.

Halasa T, Huijps K, Østerås O, Hogeveen H, 2007: Economic effects of bovine mastitis and mastitis management: A review. Vet. Q, 29, 18-31.

Heringstad B, Gianola D, Chang YM, Odegard J, Klemetsdal G, 2006: Genetic associations between clinical mastitis and somatic cell score in early firstlactation cows. J Dairy Sci, 89, 2236-2244.

Jacob KK, Radhika G, Aravindakshan TV, 2018: An in-silico evaluation of non-synonymous single nucleotide polymorphisms of mastitis resistance genes in cattle. Anim, 31 (1), 25-31.

Janzen JJ: Economic losses resulting from mastitis. A review, 1970: J Dairy Sci, 53, 1151-1161.

Krum SA, Womack JE, Lane TF, 2003: Bovine BRCA1 shows classic responses to genotoxic stress but low in vitro transcriptional activation activity. Oncogene, 22 (38), 6032.

Kumar AA, Rahal SK, Dwivedi SK, Gupta MK, 2010: Bacterial prevalence and antibiotic resistance profile from bovine mastitis in Mathura, India. Egypt. J Dairy Sci, 38, 31-34.

Rupp R, Hernandez A, Mallard BA, 2007: Association of bovine leukocyte antigen (BoLA) DRB3.2 with immune response, mastitis, and production and type traits in Canadian Holsteins. J Dairy Sci, 90 (2), 1029-1038.

Saini V, McClure JT, Léger D, Keefe GP, Scholl DT, Morck DW, Barkema HW, 2012: Antimicrobial resistance profiles of common mastitis pathogens on Canadian dairy farms. J Dairy Sci, 95 (8), 4319-4332.

Sambrook J, Fritsch EF, Maniatis T. Molecular Cloning, 1989: A Laboratory Manual Appendixes Second Edition. New York: Cold Spring Harbor Laboratory Press City?, Counrty ?.

Tepeli SÖ, Zorba NN, 2017: Çanakkale (Yenice) ilinde üretilen çiğ sütlerin bazı özellikleri ve subklinik (gizli) mastitis görülme oranı. Trakya Univ J Nat Sci, 18 (1), 41-47.

Tolone M, Mastrangelo S, Di Gerlando R, Sutera AM, Monteleone G, Sardina MT, Portolano B, 2016: Association study between $\beta$-defensin gene polymorphisms and mastitis resistance in Valle del Belice dairy sheep breed. Small Rumin Res, 136, 1821.

Wang Q, Zhang H, Fishel R, Greene MI, 2000: BRCA1 and cell signaling. Oncogene, 19 (53), 6152-6158.

Weigel KA, Shook GE, 2018: Genetic selection for mastitis resistance. Vet Clin North Am Food Anim Pract, 34 (3), 457-472.

Yalçın M, Argun MŞ, 2017: Bitlis Eren Üniversitesi Sağlık Yüksekokulu öğrencilerinin süt ve süt ürünleri 
tüketim alışkanlıklarının ve etkileyen faktörlerin belirlenmesi. BEÜ Fen Bilimleri Dergisi, 6 (1), 51-60.

Yaylak E, Akbaş Y, Özsoy AN, 2015: Siyah Alaca ile Bazı Süt Sığır Irkları Arasında Yapılan Melezlemeler ve Melez Ineklerin Performansları. SDÜ Ziraat Fakültesi Dergisi, 10 (1), 97-106.

Youngerman SM, Saxton AM, Oliver SP, Pighetti GM, 2004: Association of CXCR2 polymorphisms with subclinical and clinical mastitis in dairy cattle. J Dairy Sci, 87 (8), 2442-2448

Yuan Z, Li J, Li J, Zhang L, Gao X, Gao HJ, Xu S, 2012a: Investigation on BRCA1 SNPs and its effects on mastitis in Chinese commercial cattle. Gene, 505 (1), 190-194.

Yuan Z, Chu G, Dan Y, Li J, Zhang L, Gao X, Liu Z, 2012b: BRCA1: A new candidate gene for bovine mastitis and its association analysis between single nucleotide polymorphisms and milk somatic cell score. Mol Biol Rep, 39 (6), 6625-6631.

${ }^{*}$ Correspodence: Fadime DALDABAN

Department of Genetics, Faculty of Veterinary Medicine, Erciyes University, Kayseri, Turkey.

e-mail: ozdemir.fdm@gmail.com 